\title{
IMPLEMENTASI TQM TERHADAP MUTU INSTITUSI DALAM LEMBAGA PENDIDIKAN
}

\author{
Suhermanto, Anshari \\ Universitas Nurul Jadid \\ Paiton Probolinggo Jawa Timur \\ Radenherman45@gmail.com
}

\begin{abstract}
Abstrak: Earing the word education is certainly no stranger to the public. Education is addressed with school and learning. The word education in terms of language is derived from the word "pedagogy" namely "paid" which means child and "agogos" which means guiding. So pedagogy or education is the science of guiding children. Education can also be defined as a process of changing the attitude and behavior of a person or group in an effort to mature a human being or a student through teaching and training efforts. The word management is often heard in our daily lives. Management is used to assist us in doing things. The role of management is needed in daily life which is intended to regulate all work. Through management, all work can be done and done well and systematically. We usually get quality when we discuss about industries related to the provision or delivery of services. The field of education is one area that provides services to its customers. The intended customers in the world of education are divided into 3 groups, namely primary customers (directly involved, namely students), secondary customers (who support education such as parents), and tertiary customers (indirectly involved but have an important role in education, namely employees, community, and government).
\end{abstract}

Kata kunci: TQM, Education, quality improvement

\section{PENDAHULUAN \\ Pengertian Pendidikan}

Mendengar kata pendidikan tentu sudah tidak asing lagi di telinga masyarakat. (Baharun,

2017) Pendidikan dikatikan dengan sekolah dan belajar. Kata pendidikan secara bahasa berasala dari kata "pedagogi" yakni "paid" yang berarti anak dan "agogos" yang berarti membimbing. Jadi pedagogi atau pendidikan adalah ilmu untuk membimbing anak. Pendidikan juga dapat didefinisikan sebagai suatu proses pengubahan sikap dan perilaku seseorang atau kelompok dalam usaha mendewasakan manusia atau peserta didik melalui upaya pengajaran dan pelatihan.

Pendidikan amat berkaitan dengan institusi yang disebut sekolah. Pengertian sekolah yang dikenal oleh masyarakat pada umumnya ialah tempat untuk seseorang menimba ilmu. Kata Sekolah berasal dari bahasa latin skhhole, scola, scolae atau shkola, yang berarti waktu luang atau waktu luang. Sekolah adalah kegiatan di waktu luang bagi anak-anak di tengah kegiatan mereka yang utama, yaitu bermain dan menghabiskan waktu menikmati frase anak dan frase remaja. Kegiatan yang dapat dilakukan dalam waktu luang adalah mempelajari cara berhitung, membaca huruf-huruf, dan mengenal tentang moral (budi pekerti) dan estetika (seni). 


\section{Volume 2 Nomor 12018}

Implementasi TQM terhadap Mutu Institusi dalam Lembaga Pendidikan

Untuk mendapatkan pengertian yang lebih menyeluruh dan psati mengenai sekolah, kita dapat melihat definisi tentang sekolah, yaitu :

1. Sekolah adalah bangunan atau lembaga untuk belajar dan mengajar serta tempat menerima dan memberi pelajaran. Menurut tingkatannya, sekolah terbagi menjadi sekolah dasar, sekolah lanjutan, dan sekolah tinggi (KBBI dalam Departemen Pendidikan Nasiona : 1999).

2. Sekolah adalah sebuah lembaga yang dirancang sedemikian rupa untuk pengajaran siswa / murid di bawah pengawasan guru. Sekolah dipimpin oleh seorang kepala sekolah dan didukung oleh jajaran staf yang ada, seperti wakil kepala sekolah, Tata Usaha dan lain lain. Berikut adalah contoh struktur organisasi sekolah.

\section{Pengertian mutu Institusi Pendidikan}

Mutu biasanya kita dapatkan apabila kita membahas tentang industri yang berkaitan dengan penyediaan atau penyelenggaran jasa. Bidang pendidikan adalah salah satu bidang yang memberikan jasa kepada para pelanggannya. Pelanggan yang dimaksudkan dalam dunia pendidikan terbagi menjadi 3 kelompok, yaitu pelanggan primer (terlibat secara langsung, yaitu peserta didik), pelanggan sekunder (yang mendukung pendidikan seperti orang tua), dan pelanggan tersier (secara tidak langsung terlibat tetapi memiliki peranan penting dalam pendidikan, yaitu karyawan, masyarakat, dan pemerintah). Jadi di dalam bidang pendidikan pun diperlukan adanya mutu.

Pendidikan dapat dikatakan bermutu atau memiliki mutu yang baik apabila proses belajar mengajar yang terlibat di dalamnya berjalan dengan baik dan lancar sehingga hasil yang didapatkan memuaskan (Mundiri, 2017). Proses belajar mengajar dapat berjalan dengan lancar apabila orang-orang yang terlibat di dalamnya dapat berkomunikasi dengan baik, tersedianya lingkungan belajar yang nyaman dan aman, serta didukung oleh saran dan prasarana yang memadai. Selain itu, mutu institutsi pendidikan dapat dilihat dari kemampuan sekolah dalam menghasilkan prestasi baik dari siswa maupun sekolah itu sendiri dalam kurun waktu tertentu, sehingga melalui lulusan-lulusan yang berprestasi baik, dapat dikatakan bahwa sekolah tersebut memiliki mutu yang baik pula.

Jadi dapat disimpulkan bahwa mutu institusi pendidikan adalah suatu tolak ukur kemampuan lembaga atau isntitusi pendidikan dalam menyelenggarakan proses belajar mengajar yang baik, aman, dan nyaman dimana proses tersebut didukung oleh sarana dan prasarana yang memadai dengan tujuan untuk memberikan kepuasan serta keberhasilan kepada peserta didik.

Dalam rangka menyelenggarakan kegiatan belajar mengajar yang baik, aman, dan nyaman atau dapat juga disebut kondusif, maka institusi terkait, yaitu sekolah serta instansi- 
$\underset{\text { Volume } 2 \text { Nomor } 12018}{\text {-tanziman }} \begin{aligned} & \text { Suhermanto, Anshari } \\ & \text { Implementasi TQM terhadap Mutu Institusi dalam Lembaga Pendidikan }\end{aligned}$

instansi lainnya harus menerapkan manajemen mutu terpadu atau disebut juga Total Quality Management (TQM).

\section{Total Quality Management ( Manajemen Kualitas Terpadu )}

Pengertian Manajemen

Kata manajemen seringkali kita dengar dalam kehidupan kita sehari-hari. Manajemen digunakan untuk membantu kita dalam mengerjakan sesuatu.Peran manajemen sangat dibutuhkan dalam kehidupan sehari-hari yang diperuntukkan dalam hal pengaturan segala pekerjaan. Melalui manajemen, segala pekerjaan dapat dikerjakan dan diselesaikan dengan baik dan secara sistematis.

\section{Fungsi - fungsi Dalam Manajemen}

Melihat beberapa pendapat dari para ahli di atas, kita dapat menarik beberapa hal penting ketika berbicara tentang manajemen, yaitu bahwa dalam proses manajemen pada hakikatnya melibatkan 4 jenis kegiatan atau aktivitas yang disebut sebagai tindakan manajemen yang kemudian menjadi fungsi utama dalam manajemen, yaitu :

1. Fungsi perencanaan

Perencanaan merupakan proses dalamm mengartikan apa yang menjadi tujuan sebuah organisasi yang ingin dicapai, kemudian dari tujuan tersebutmaka orang-orang yang terlibat di dalam organisasi tersebut harus membuat atau merancang strategi dalam mencapai tujuan tersebut dan dapat mengembangkan suatu rencana aktivitas suatu kerja organisasi. Perencanaan dalam manajemen sangat penting karena inilah awalan dalam melakukan sesuatu dan dalam proses ini menyangkut penetapan tujuan dan target yang hendak dicapai, merumuskan taktik dan strategi yang akan digunakan, menetapkan sumber daya atau peralatan apa yang diperlukan, serta menentukan indicator atau standar keberhasilan dalam mencapai tujuan dan target.

\section{Fungsi pengorganisasian}

Langkah berikutnya adalah pengorganisasian, yaitu bagaimana cara kita dapat mengalokasikan sumber daya, merumuskan dan menetukan tugas, serta menetapkan prosedur yang dibutuhkan, menentukan struktur organisasi untuk mengetahui bentuk garus tanggung jawab dan kewenangan, melakukan perekrutan, penyeleksian, pelatihan dan pengembangan sumber daya manusia atau sumber daya tenaga kerja serta menempatkan tiap-tiap orang dalam posisi yang tepat sesuai dengan potensi dan keahlian yang dimiliki. 
$\underset{\text { Volume } 2 \text { Nomor } 12018}{1 \text {-tanzim }} \begin{aligned} & \text { Suhermanto, Anshari } \\ & \text { Implementasi TQM terhadap Mutu Institusi dalam Lembaga Pendidikan }\end{aligned}$

3. Fungsi Pengarahan dan Implementasi

Fungsi pengarahan dan implementasi adalah untuk menengarahkan dan menerapkan proses kepemimpinan, pembimbingan, dan pemberian sebuah motivasi untuk tenaga kerja agar dapat termotivasi untuk bekerja dengan efektif dan efisien untuk mencapai tujuan bersama, memberikan tugas dan penjelasan yang teratur mengenai pekerjaan dan menjelaskna kebijakan yang telah ditetapkan.

4. Fungsi pengawasan dan pengendalian

Proses pengawasan dan pengendalian dilakukan untuk memastikan bahwa seluruh rangkaian kegiatan yang telah direncanakan, diorganisasikan dan diterapkan dapat berjalan sesuai dengan harapan atau target, walaupuntidak menutup adanya kemungkinan hasil yang dicapai sedikit berbeda dengan yang telah ditentukan sebelumnya karena kondisi lingkungan organisasi. (Mundiri, 2018) Fungsi dari pengawasan dan pengendalian adalah untuk mengevaluasi suatu keberhasilan dalam mencapi tujuan dan target sesuai dengan tolak ukur yang telah ditentukan; mengambil langkah klarifikasi dan koreksi atas keanehan yang mungkin ditemukan dalam kegiatan sehari-hari, dan membuat alternatif solusi ketika ada masalah yang rumit berkaitan dengan adanya kendala dalam mencapai tujuan dan target.

\section{Pengertian Manajemen Mutu Terpadu (Total Quality Management)}

Total Quality manajemen atau Manajemen Mutu Terpadu adalah perluasan dan pengembangan dari jaminan mutu. TQM adalah tentang usaha menciptakan sebuah kultur mutu yang mendorong semua anggota stafnya untuk memuaskan para pelanggan. Dalam konsep mutu terpadu, pelanggan adalah raja. Konsep ini berbicara tentang bagaimana memberikan sesuatu yang diinginkan oleh pelanggan, serta kapan dan bagaimana mereka menginginkannya. Konsep ini disesuaikan dengan perubahan harapan dan gaya pelanggan dengan cara mengemas hasil produksi dan jasa yang sesuai dengan kebutuhan mereka.

Dengan memuaskan pelanggan, bisa dipastikan mereka akan kembali lagi dan memberitahu teman-temannya tentang hasil produksi atau layanan tersebut. Ini disebut dengan istilah mutu yang menjual (sell-on quality).Persepsi dan harapan pelanggan tersebut diakui sebagai sesuatu yang berjangka pendek dan bisa berubah-ubah. Demikian juga dengan organisasi, ia harus menemukan metode-metode yang tepat untuk mendekatkan diri dengan pelanggan agar dapat merespon perubahan selera, kebutuhan, dan keinginan pelanggan.

Jadi dapat disimpulkan bahwa Total Quality Management atau Manajemen Mutu Terpadu adalah sebuah manajemen terhadap pengembangan dan perbaikan mutu yang dilakukan secara terus-menerus dengan menggunakan alat-alat penunjang agar dapat memenuhi kebutuhan pelanggan yang menghasilkan kepuasan dari pelanggan. 


\section{Strategi Peningkatan Mutu Berorientasi Standar Nasional Pendidikan di Lembaga}

\section{Pendidikan Islam}

Sebelum kita membahas mengenai hubungan antara total quality management dengan peningkatan mutu institusi pendidikan, ada baiknya kita , mengulas kembali definisi dari TQM. TQM biasanya digunakan untuk mendeskripsikan dua gagasan yaitu filosofi perbaikan secara terus-menerus dan alat-alat serta teknik-teknik, seperti brainstorming, analisa lapangan yang digunakan untuk membawa peningkatan mutu. Jadi TQM adalah sebuah pola pikir sekaligus aktivitas praktis. TQM sebagai sebuah pendekatan mencari sebuah perubahan permanen dalam tujuan sebuah organisasi dari tujuan kelayakan jangka pendek menuju tujuan perbaikan mutu jangka panjang. Institusi melakukan inovasi secara konstan melakukan perbaikan secara terus menerus. Semangat tersebut menciptakan sebuah upaya sadar untuk menganalisis apa yang sedang dikerjakan dan merencanakan perbaikannya.

Hubungannya dengan peningkatan mutu institusi pendidikan adalah agar mutu sebuah institusi pendidikan dapat dikembangkan dan ditingkatkan ke arah yang lebih baik, maka institusi pendidikan perlu menerapkan TQM di dalam organisasinya. Institusi pendidikan perlu secara sadar mengkaji terus menerus perkembangan kebutuhan pelanggan mereka, melakukan perbaikan dan meningkatkan mutu institusi tersebut sehingga kepuasan pelanggan tercapai.Pertumbuhan dan peningkatan sebuah institusi bersumber dari kesesuaian layanan institusi dengan kebutuhan pelanggan. Mutu harus sesuai dengan harapan dan keinginan pelanggan. Sebagai pencetus TQM, Deming mengemukakan bahwa "Quality is what the customer says it is." Dalam konteks pendidikan, TQM adalah suatu cara untuk menjamin kualitas standar dalam pendidikan.

Lembaga pendidikan memiliki peran yang sangat penting dan strategis dalam menyiapkan sumber daya manusia untuk menghadapi tantangan global pada millennium ketiga ini (Fauzi, 2015). faktor kunci dalam menentukan kualitas lulusan adalah kualitas pendidikan yang diperolehnya selama belajar, sedangkan kualitas pendidikan ditentukan oleh kualitas lembaga tempat lulusan belajar.

Praktis kepada setiap institusi pendidikan dalam menambahi kebutuhan, keinginan, dan harapan para pelanggannya saat ini dan masa yang akan datang. Organisasi TQM memerlukan strategi yang berjalan untuk memenuhi keperluan pelanggan. Pendidikan menghadapi tantangan yang cukup besar dalam hubungannya dengan pelanggan baik internal maupun eksternal.Sebagian besar pelanggan pada mulanya tidak menerima informasi yang cukup tentang layanan yang ditawarkan dan hal apa yang mengindikasikan mutunya. Selain itu, harapan-harapan para pelanggan sangat beraneka dan kadang kala bertentangan satu sama lain. Terkadang, pelanggan juga sulit membedakan antara mutu program-program tertentu dari 
1-tanZim $\begin{aligned} & \text { Suhermanto, Anshari } \\ & \text { Implementasi TQM terhadap Mutu Institusi dalam Lembaga Pendidikan }\end{aligned}$ Volume 2 Nomor 12018

sebuha institusi dengan reputasi institusi tersebut. Persepsi pelajar tentang perubahan mutu akan terus berkembang melalui institusi, saat kepercayaan diri dan pengalaman mereka mulai berkembang.

Kesulitan selanjutnya adalah para pelanggan pendidikan memainkan peranan penting dalam mutu belajar mereka masing-masing. Pelanggan memiliki fungsi yang unik dalam menentukan mutu apa yang mereka ingin terima dari pendidikan dan institusinya. Hal penting lainnya adalah memperjelas apa yang ditawarkan institusi dan apa yang diharapkan pelajar. Hal ini disebabkan karena pendidikan adalah tentang pembelajaran masyarakat. Jika TQM bertujuan untuk memiliki relevansi dalam pendidikan, maka harus memberi penekanan pada mutu pelajar.

Hal ini tidak akan terwujud jika TQM tidak memberi kontribusi yang substansial bagi mutu dalam pendidikan. Pada saat sebagian besar institusi pendidikan dituntut untuk mengerjakan lebih baik lagi, penting baginya untuk memfokuskan diri pada aktivitas utama, yakni pembelajaran. Institusi pendidikan yang menerapkan prosedur mutu terpadu harus menangkap secara serius isu-isu tentang gaya dan kebutuhan pembelajaran untuk menciptakan strategi individualisasi dan deferensiasi dalam pembelajaran.

Pelajar adalah pelanggan utama, dan jika model pembelajaran tidak memenuhi kebutuhan individu masing-masing mereka, maka itu berarti bahwa institusi pendidikan tersebut tidak dapat mengkalim bahawa ia telah mencapai mutu terpadu. Institusi pendidikan memiliki kewajiban untuk membuat pelajar sadar terhadap variasi metode pembelajaran yang diberikan kepada mereka.Institusi pendidikan harus memberi pelajar kesempatan untuk mencontoh pembelajaran dalam variasi model yang berbeda. Institusi harus memahami bahwa beberapa pelajar juga suka pada kombinasi beberapa gaya belajar dan institusi harus mencoba untuk cukup fleksibel dalam memberikan pilihan tersebut.

Institusi pendidikan juga perlu menggunakan hasil pengawasan formal untuk menetapkan keabsahan program-programnya.Institusi pendidikan harus siap untuk melakukan langkahlangkah perbaikan terhadap kinerja pelajar yang belum sesuai dengan harapan dan keinginan mereka.Sebagaimana yang telah diketahui oleh para guru, hal ini bukan hal yang mudah, karena hal ini bisa saja adalah menjadi pengalaman emosional dan dapat membawa perubahan yang tak terduga. Hal yang perlu ditegaskan adalah langkah-langkah perbaikan tersebut bertujuan untuk memberikan motivasi dan pengalaman praktis kepada para pelajar tentang penggunaan TQM yang dapat menyesuaikan diri dalam situasi apa pun. Jadi dapat disimpulkan bahwa dengan semakin baiknya penerapan manajemen mutu terpadu pada sebuah institusi pendidikan maka peningkatan mutu institusi pendidikan tersebut dapat dilihat secara nyata dan dirasakan hasilnya oleh para pelanggan, yang dalam hal ini adalah para peserta didik atau pelajar. 


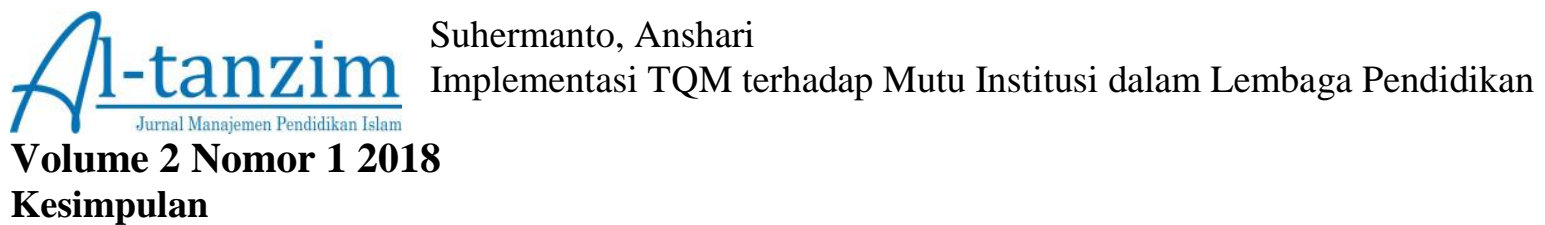

Keberhasilan suatu insititusi pendidikan dalam meningkatkan mutu ditentukan oleh penerapan manajemen mutu terpadu yang ada di dalam institusi terkait.Untuk keberhasilan penerapan Total Quality Management dalam pendidikan tidaklah mudah karena diperlukan kebutuhan dan kerjasama yang baik antara pihak terkait dan lembaga pendidikan setempat sebagai pihak yang berhubungan langsung dengan masyarakat.Oleh karena itu perlu adanya kejelasan secara sistematik dalam memberikan kewenangan antar institusi terkait. Jika manajemen ini diterapkan sesuai dengan ketentuan yang ada dengan segala dinamika dan fleksibilitasnya, maka akan menjadi perubahan yang cukup efektif bagi pengembangan dan peningkatan mutu pendidikan.

Dalam menerapkan TQM pada institusi pendidikan maka ada beberapa langkah yang perlu diperhatikan, yaitu kepemimpinan dan komitmen mutu, bagaimana cara menggembirakan pelanggan, menentukan fasilitator mutu, membentuk kelompok pengendali dan koordinator mutu, seminar meanajemen senior untuk evaluasi program, merencanakan strategis mutu, melibatkan konsultan eksternal, pelatihan mutu bagi staf, menghitung biaya mutu, mengoptimalkan alat dan teknik mutu melalui pengembangan kelompok kerja yang efektif, dan evaluasi program secara rutin.

Komitmen terhadap mutu harus menajdi peran utama bagi seorang pemimpin, karena TQM adalah proses atas ke bawah (top-down). Sering kali terjadi kegagalan dalam mutu karena pemimpin yang kurang mendukung proses dan komitmen untuk inisiatif tersebut. Oleh sebab itu, penerapan TQM adalah tanggung jawab semua pihak terkait apabila ingin melihat adanya peningkatan dalam mutu institusi pendidikan.

\section{Daftar Pustaka}

Baharun, Hasan. Pengembangan Kurikulum: Teori dan Praktik (Konsep, Prinsip, Model, Pendekatan dan Langkah-langkah Pengembangan Kurikulum PAI), 2017.

Farikhah, M.Pd, Dra. Hj.Siti Manajemen Lembaga Pendidikan Yogyakarta : Penerbit Aswaja Pressindo. (2015).

Fauzi, Ahmad. Membangun Epistemologi Pendidikan Islam Melalui Kepemimpinan Spiritual : Suatu Telaah Diskursif. 2015.

http://www.seputarpengetahuan.com/2015/02/15-pengertian-pendidikan menurut-para-ahli.html (diunduh pada tanggal 20 Juni 2018 pukul 13.00).

Mundiri, Akmal. Organizational Culture Base On Total Quality Management In Islamic Educational Institution, 2017.

Mundiri, Akmal. Perkembangan Dan Konsep Dasar Manajemen Humas Dalam Dunia Pendidikan: Tinjauan Historis, 2018.

Sallis, Edward Total Quality Management in Education New York : Penerbit Psychology Press. (2002). 